\title{
ARABIZMI U BOSANSKOM JEZIKU I ZNAČAJ NJIHOVOG POZNAVANJA U NASTAVI ARAPSKOG JEZIKA
}

\section{Sažetak}

Arabizmi su riječi arapskog porijekla koje su većim dijelom posredstvom turskog jezika prenesene i udomaćile se u bosanskom jeziku. Arabizmi se često izučavaju pod imenom turcizmi, jer su većim dijelom u bosanski jezik stigli putem turskoga jezika, pa je ustaljeno mišljenje da se radi o turcizmima, iako se pod terminom turcizmi podrazumijevaju ne samo riječi porijeklom iz turskog, nego i one iz arapskog i perzijskog jezika.

Cilj rada je predstavljanje arabizama u bosanskom jeziku: definisanje pojma arabizam, kao $i$ razlike između arabizama $i$ turcizama, pojašnjenje kako su arabizmi dospjeli na naše prostore, te koliki je broj arabizama u našem jeziku. U radu su navedene fonetske $i$ semantičke promjene koje su se desile prilikom njihovog ulaska u bosanski jezik, uz navođenje praktičnih primjera arabizama u našem jeziku.

U radu je, također, posvećena pažnja važnosti $i$ značaju proučavanja arabizama, posebno u nastavi arapskog jezika.

Ključne riječi: arabizam, turcizam, orijentalizam, glasovne promjene, hibridne riječi, arapski jezik, turski jezik

\section{Uvod}

Snažnim uticajima arapsko-islamske kulture nisu se uspjeli oduprijeti mnogi narodi, pa tako ni jezici naših podneblja. Iz arapskog jezika $^{2}$ je putem turskoga u bosanski jezik, ali i susjedne jezike, prenešen značajan broj riječi koje jedni nazivaju tuđicama, drugi orijentalizmima, a treći turcizmima. Ma kako ih nazivali, bitno je da se svi slažu da je taj uticaj postojao i da u jezicima ovog podneblja postoji značajan broj riječi arapskog porijekla.

\footnotetext{
${ }^{1}$ Islamski pedagoški fakultet u Bihaću

${ }^{2}$ Pod arapskim jezikom podrazumijevamo arapski književni ili standardni jezik.
} 
Izučavanje prošlosti BiH ili običaja naroda na ovim prostorima, bez dobrog poznavanja pojmova kao što su arabizmi i turcizmi, bilo bi nepotpuno i šturo. S obzirom na višestoljetnu dominaciju Osmanlija i njihove državne ideologije na ovim prostorima, sasvim je jasno da će njihova kultura, jezik i običaji ostaviti dubok trag na kulturu, jezik i običaje domicilnog stanovništva. Prema tome, izučavanje arabizama ili turcizama je od velikog značaja za izučavanje kulture, jezika i prošlosti ovih krajeva općenito.

Iako je turski jezik jezik po svom porijeklu i strukturi sasvim različit od arapskog, ipak je preuzeo od njega mnoštvo riječi, a izvjestan broj takvih arapskih riječi, doživjevši već u turskom jeziku razne semantičke, a još više fonetske promjene, prešao je i u naš jezik. $^{3}$

Cilj rada je upoznati se sa arabizmima u bosanskom jeziku: definisati pojam arabizam, ukazati na značaj i brojnost arabizama $u$ bosanskom jeziku, te ukazati na značaj poznavanja arabizama na polju izučavanja arapskog jezika u nastavi.

Ovaj rad obuhvata i navođenje nekoliko primjera arabizama $\mathrm{u}$ bosanskom jeziku, njihovo originalno značenje u arapskom jeziku, te pojašnjava neke fonetske i semantičke promjene do kojih je dolazilo prilikom ulaska arabizama u bosanski jezik.

Moj doprinos na polju istraživanja arabizama jeste $u$ objedinjavanju okvirnih rezultata dosadašnjih istraživanja ove teme na jednome mjestu i prezentacija rezultata istraživanja koje sam proveo među studentima Islamskog pedagoškog fakulteta u Bihaću o značaju izučavanja arabizama u nastavi arapskog jezika.

Literatura na ovu temu je oskudna i rijetki su autori koji su ovoj temi, usprkos njenoj važnosti, posvećivali veću pažnju. Nesumnjivo, najveći doprinos prezentiranju ove teme, prema onome što sam uspio istražiti, dali su Teufik Muftić u svojim radovima objavljenim u Prilozima za orijentalnu filologiju Orijentalnog instituta u Sarajevu, Abdulah Škaljić u svom prestižnom djelu Turcizmi u srpskohrvatskom jeziku i Hanka Vajzović u djelu Orijentalizmi u književnom djelu. Međutim, zanimljivo je da niko nije našao za shodno da

\footnotetext{
${ }^{3}$ Muftić Teufik, O arabizmima u srpskohrvatskom jeziku, u „Prilozi za orijentalnu filologiju X-XI“, Orijentalni institut, Sarajevo, 1960-61., str. 5.
} 
isključivo tematiku arabizama obradi sa svih aspekata $\mathrm{i}$ da to prezentira široj javnosti u printanom izdanju, izuzev dva Muftićeva rada koja su obradila dva značajna segmenta arabizama.

Da bi govorili o arabizmima, prije toga, neophodno je da definišemo pojam arabizam, a obzirom da se isti isprepliće sa pojmom turcizam, smatramo da je potrebno pojasniti i pojam turcizam.

\section{1. Šta su to turcizmi?}

Turcizmi su riječi koje su u bosanski jezik ušle putem turskog jezika, bez obzira da li one bile turskog, arapskog ili perzijskog porijekla. Posebno su karakteristični za jezike naroda, koji su bili pod vlašću Osmanskog carstva (grčki, bošnjački, bugarski, makedonski, srpski, jermenski). Neke od riječi arapskog i perzijskog jezika, preko turskog jezika, dospjele su na Balkan, pa se smatraju turcizmima. Dakle, čak i riječi koje vode porijeklo iz arapskog i perzijskog jezika, a na prostore Balkana su došle putem turskog jezika, imaju status turcizama.

Taj stav potvrđuje Alija Isaković, autor Rječnika bosanskoga jezika, koji o turcizmima kaže da su to "riječi ili izrazi u našem jeziku primljeni posredstvom turskog jezika“. 4 Također, Bratoljub Klaić o turcizmima kaže sljedeće: "Turcizam je riječ ili izraz turskog podrijetla; mnogi su turcizmi arapskog ili perzijskog podrijetla, ali kako su ih k nama donijeli Turci, svrstavamo ih pod taj naziv. ${ }^{\text {"5 }} \mathrm{S}$ tim se slaže i Abdulah Škaljić, autor djela Turcizmi u srpskohrvatskom jeziku koji smatra da zbog činjenice da su u naše jezike došle putem turskog jezika, zaslužuju da budu identifikovane kao turcizmi. ${ }^{6}$ Muhamed Hadžijahić u tekstu pod naslovom Turcizmi u hrvatskom jeziku o turcizmima kaže sljedeće: „Ove riječi poznate pod skupnim nazivom ,turcizmi“, sadržavaju osim izraza čisto turskog podrijekla još više arapskih, a uz to i perzijskih, te nešto grčkih i drugih riječi iz istočnih jezika, koje su do Kemalovih reformi bile u tako čestoj

\footnotetext{
${ }^{4}$ Isaković Alija, Rječnik bosanskoga jezika, Bosanska knjiga, Sarajevo, 1995., str. 330 .

${ }^{5}$ Klaić Bratoljub, Rječnik stranih riječi, Nakladni zavod Matice Hrvatske, Zagreb, 1990., str. 1384.

6 Škaljić Abdulah, Turcizmi u srpsko-hrvatskom jeziku, Svjetlost, Sarajevo, 1966., str. 24.
} 
jezičnoj upotrebi kod Turaka." ${ }^{\text {"7 }}$ Dr. Teufik Muftić smatra da je to zato što su prošle fazu prilagođavanja i pravopisu turskog jezika, odakle su ih ovdašnji jezici preuzeli.

Međutim, ima i autora koji smatraju da pojam turcizam označava sve tuđice u jezicima bivše Jugoslavije, bez obzira na jezik porijekla, dok dr. Senahid Halilović smatra da se ova grupa riječi naziva orijentalizmima (riječi iz turskog, arapskog i perzijskog jezika). ${ }^{8}$ Dakle, pored termina tuđice, turcizmi i arabizmi, ima $\mathrm{i}$ onih koji smatraju da se ova grupa riječi može nazivati i orijentalizmima.

\section{2. Šta su to arabizmi?}

Arabizmi su riječi arapskog porijekla koje su posredstvom turskog jezika i na neki drugi način prenesene i udomaćile se u bosanskom jeziku.

Korist podjele riječi orijentalnog porijekla, ili tuđica općenito, na turcizme, arabizme i farsizme (ili persizme) je zbog lakšeg utvrđivanja iz kojeg jezika potiču, kako bi se lakše upoređivala značenja u njihovom originalnom i bosanskom jeziku, te njihovom razvoju, jer su mnoge riječi doživjele određenu semantičku promjenu.

\section{Broj arabizama u bosanskom jeziku}

Broj arabizama ili broj turcizama koji vode porijeklo iz arapskog jezika teško je precizno odrediti.

Abdulah Škaljić smatra da je broj turcizama, općenito, 8742 riječi, dok od toga broja značajan dio otpada na arabizme, tj. turcizme koji vode porijeklo iz arapskog jezika. Muftić smatra da od ukupnog broja turcizama, njih oko 3800 ima arapsko porijeklo. ${ }^{9}$ Međutim, Šaćir

\footnotetext{
${ }^{7}$ Hadžijahić Muhamed, Turcizmi u hrvatskom jeziku, autor: Muhamed Hadžijahić, objavljen u "Hrvatski narod", god. VI., br. 975, 3. ožujka 1944., str. 4) Vidi: http:/www.hercegbosna.org/forum/kultura-knjizevnostumjetnost/ turcizmi-uhrvatskom-jeziku-muhamedhad-ijahi-t2067.html

${ }^{8}$ Halilović Senahid, Pravopis bosanskoga jezika - priručnik za škole, Dom štampe, Zenica, 1999., str. 55.

9 Muftić Teufik, Prilog semantičkom izučavanju arabizama u srpskohrvatskom jeziku, u „Prilozi za orijentalnu filologiju XVIII-XIX“, Orijentalni institut, Sarajevo, 73., str. 59.
} 
Sikirić i Fehim Nametak smatraju da je ukupan broj arabizama u bosanskom ili srpsko-hrvatskom jeziku blizu 10000 riječi. $^{10}$ Isto mišljenje iznosi dr. Hanka Vajzović u svom radu Orijentalizmi $u$ književnom djelu. ${ }^{11}$

Međutim, bilo je i onih koji tvrde da je taj broj znatno manji, pa tako dr. Safvet-beg Bašagić smatra da je broj turcizama arapskog porijekla ili arabizama 1150 riječi, dok je 980 čisto turskih, a 570 perzijskih riječi. $^{12}$

Prema tome, većina autora se slaže oko toga da broj arabizama premašuje nekoliko hiljada riječi i predstavlja najmanje polovicu ukupnoga broja riječi orijentalnog porijekla u našem jeziku.

\section{Važnost i značaj proučavanja arabizama}

Proučavanje arabizama je važno zbog nekoliko razloga, od kojih izdvajamo:

a) zbog činjenice da jezici i književnosti naroda bivše Jugoslavije obiluju arabizama, pa je stoga nezamislivo da se ne pridaje pažnja njihovom izučavanju, jer bi to značilo zapostavljanje dragocjenog književnog bogatstva u kojem se ta vrsta riječi koristi,

b) veliki broj narodnih izreka, poslovica, historijskih dokumenata koji su nastajali u periodu osmanske vladavine Balkanom moraju biti adekvatno pojašnjeni i obrađeni kako bi se kvalitetno shvatila prošlost ovih krajeva, kao što izučavanje arabizama doprinosi boljem shvatanju imena pojedinih spomenika kulture na ovim prostorima,

c) izučavajući arabizme u bosanskom jeziku dolazimo do zaključka da je arapsko-islamska kultura imala indirektan uticaj na stanovništvo Balkana; njihovu kulturu, jezik i običaje. Također, dolazimo do zaključka da je značajan dio običaja i kulture, za koje smo pretpostavljali da su izvorno osmanski, da oni, ustvari, svoje

10 Nametak Fehim, Književnost bosanskohercegovačkih muslimana na turskom jeziku, „Treći program Radio Sarajeva“, Sarajevo, 1978., br. 19., str. 550.

11 Vajzović Hanka, Orijentalizmi u književnom djelu, Institut za jezik, Sarajevo, 1999., str. 13.

12 Škaljić Abdulah, Turcizmi u srpsko-hrvatskom jeziku, Svjetlost, Sarajevo, 1966., str. 24. 
korijene vuku iz arapsko-islamskog kulturološkog kruga. Spoznaja o broju riječi koje se smatraju arabizmima jasno ukazuje koliki je uticaj ostavila arapsko-islamska kultura na same Osmanlije, a putem Osmanlija i na naše podneblje, običaje, mentalitet, razmišljanje i stil življenja.

Također, bitno je ukazati na jedan važan segment kada su u pitanju turcizmi. Naime, kako smo to prethodno naglasili, pod turcizmima podrazumijevamo riječi koje vode porijeklo iz turskog jezika, ali i riječi koje vode porijeklo iz arapskog jezika, riječi koje su vid kombinacije arapskog i turskog, kao i riječi koje sadrže u sebi jedan dio arapskog, a drugi perzijskog jezika, a sve su zajedno putem turskog jezika prenesene na naše podneblje. Sve to, nedvosmisleno, ukazuje na međusobnu nadogradnju i međuuticaj koji je bio prisutan među različitim nacijama.

\section{Nastanak i širenje arabizama}

Iako su riječi istočnjačkog porijekla ušle u jezik dolaskom Osmanlija, ne može se poreći da je bilo i ranijih sličnih uticaja istočnjačkih jezika na jezike Balkana. Poznato je da su pojavom Avara u Panonskoj niziji i njihovim dodirom sa balkanskim stanovništvom, posebno sa Slovenima, uslijedili izvjesni tursko-tatarski uticaji, koji su ostavili traga na balkanske jezike. ${ }^{13}$ Međutim, ovi uticaji su ograničeni i tiču se samo malog broja riječi.

Glavni uticaji počinju dolaskom Osmanlija na ove prostore. Obično se smatra da je prisustvo stranih riječi u jeziku rezultat miješanja dvaju naroda. Turcizme su najviše širili turski vojnici, administracija, domaći muslimani, te činovnici i trgovci. ${ }^{14}$

Važno je napomenuti da su Turci na Balkan donijeli jednu novu civilizaciju, koja sa sobom nosi mnoštvo novih shvatanja i zakona, što podrazumijeva unošenje novih pojmova i ustanova.

\footnotetext{
13 Škaljić Abdulah, Turcizmi u srpsko-hrvatskom jeziku, str. 12-13. 14 Ibid.
} 
Prema mišljenju Abdulaha Škaljića ${ }^{15}$, dva su činioca odigrala važnu ulogu u prenošenju i širenju turcizama, pa i onim koji imaju arapsko porijeklo, na jezike Balkana, a to su:

a) Građani ovih govornih područja koji su se školovali $u$ Carigradu, koji se nisu mogli otresti uticaja turskog i arapskog jezika, pa su u krugu svog djelovanja pravili jednu dozu kompromisa između turskog, arapskog i maternjeg jezika, a to se posebno ogledalo u radu vjerskih škola (medresa), mekteba, kao i vjerskim propovijedima vazovima.

b) Narodne pjesme, epske i lirske, koje su nastajale $u$ spomenutom periodu, bile su protkane mnoštvom turcizama, tj. i arabizama.

Dr. Muftić ovome dodaje još jedan razlog, a to je:

c) Izvjestan broj arabizama je ušao u bosanski jezik putem evropskih jezika (njemački, francuski, talijanski, španski, itd., koji su tokom srednjeg vijeka poprimili jedan broj stručnih termina porijeklom iz arapskog jezika, posebno iz pojedinih naučnih oblasti, poput astronomije, matematike, medicine, itd. ${ }^{16}$

Pored ova tri, smatram da je značajno da se naglasi i četvrti razlog nastanka i širenja arabizama na našim prostorima, koji je zasigurno ostavio nimalo manji uticaj od prethodno spomenutih, a to su:

d) Riječi koje su direktno vezane ili su sastavni dio vjerskih obreda, koji se obavljaju na arapskom jeziku, poput namaza i drugih vjerskih obaveza. Ove riječi arapskog porijekla odigrale su značajnu ulogu u širenju i ukorijenjivanju arabizama u jezicima ovih podneblja, a posebno među muslimanima koji su iste obrede prakticirali, a neke od njih prakticiraju svakodnevno i dan-danas.

Ova zadnja vrsta je danas posebno zastupljena i, za razliku od drugih riječi koje djelomično pod uticajem primjene savremenih tehnologija iščezavaju, ona ostaje i njena opstojnost je vezana za odnos muslimana ovih prostora prema svojoj vjeri.

15 Ibid.

${ }^{16}$ Muftić Teufik, O arabizmima u srpskohrvatskom jeziku, str. 5. 


\section{Fonetske promjene koje su se desile prilikom ulaska arabizama u bosanski jezik}

Fonetske ili semantičke promjene ${ }^{17}$ koje su se desile prilikom ulaska arapskih riječi u bosanski jezik su vrlo znatne, što je i prirodno, ukoliko se u obzir uzmu velike strukturalne, fonetičke, semantičke i druge razlike između bosanskog $\mathrm{i}$ arapskog jezika, ali i arapskog $\mathrm{i}$ turskog jezika, jezika posrednika.

Kako smo to prethodno istaknuli, arabizmi su u jezike ovih podneblja došli putem turskog jezika. Dakle, oni su, prije nego su bili transformirani i prilagođeni fonetici i pravopisu bosanskog jezika, bili transformirani i prilagođeni fonetici i pravopisu turskog jezika, da bi zatim isti proces bio nastavljen sa turskog na bosanski jezik.

Fonetske promjene koje su se desile prilikom ulaska arabizama u bosanski jezik možemo podijeliti u tri kategorije: a) promjene konsonanata, b) promjene vokala, i c) tvorba novih riječi.

Prvo: Promjene konsonanata

Jedan dio konsonanata arapskog jezika (njih 15) približno se podudaraju sa konsonantima bosanskog jezika, a to su: - b,

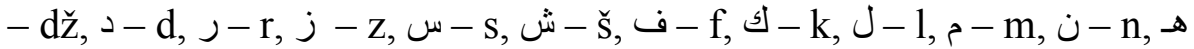
- h, - j, i oni su zamijenjeni podudarnim konsonantima. Preostali konsonanti (njih 13) su nepoznanica za naš glasovni sistem i oni su prilagođeni ili su doživjeli neke druge promjene.

Bitno je naglasiti da se neke promjene nisu desile u bosanskom, nego $\mathrm{u}$ turskom jeziku, a mi smo ih preuzeli promijenjene $\mathrm{i}$ prilagođene fonetskom sistemu turskog jezika.

Fonetske promjene na suglasnicima su mogle biti:

a) zamjena suglasnika, npr.:

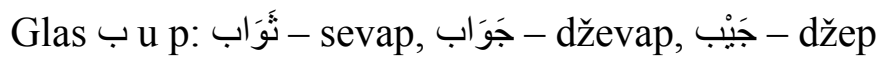

Glas ثحديث - hadis

Glas ث مِيرَاث : miraz

\footnotetext{
${ }^{17} \mathrm{U}$ ovom dijelu rada (fonetske i semantičke promjene) oslanjamo se na radove dr. Teufika Muftića o arabizmima objavljene u „Prilozima za orijentalnu filologiju“, Orijentalni institut, Sarajevo.
} 
Glas ضَرْض - farz

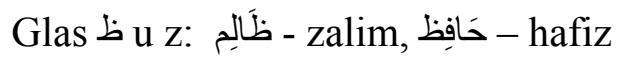

Glas د u t: عِنَاد - inat

Glas ل u lj: سَبَيل - sebilj

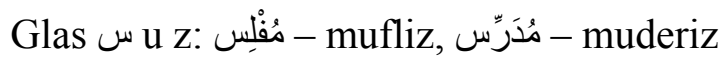

Glas bu d: قَطَائف - kadaif

Glas ص z: صَنْعَة - zَخْصُوص - mahsuz, مِقَصنّ - makaze

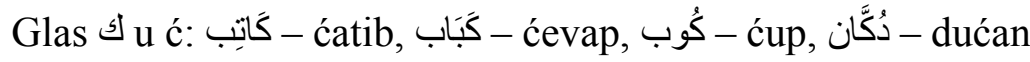

Glas خ u g: مَخَازنِن - magazin

Glas خ u k: شَيَنْ - šeik

Glas عu h: سَاعَة - sahat

Glas \& u h: آلَّ halat

Glas \& u j: بَ - belaj.

b) gubljenje suglasnika:

Neki suglasnici su se u nekim riječima potpuno izgubili, poput glasova \& $\mathrm{i} \varepsilon$, dok neke izgovaraju isključivo muslimani ovih podneblja, dok ih nemuslimani izostavljaju, poput tri varijante glasa h: ح, $\dot{\tau}, \rightarrow$.

Udvostručeni suglasnici su pojednostavljeni, iako ima izuzetaka gdje muslimani ovog podneblja izgovaraju pojedine riječi sa udvostručenim suglasnikom.

c) premetanje suglasnika (metateza), a njoj se pribjegava zbog lakšeg izgovora ili pod uticajem narodne etimologije, npr.: لََْْنَ - nalet,

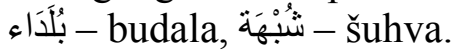

Drugo: Promjene vokala

Književni arapski jezik obilježava u pismu redovno samo tri duga vokala (transliterarirana obično kao $\bar{a}, \overline{1}$ i $\bar{u}$ ) i diftonge (sa uobičajenom transliteracijom: au, ai), ali opet pomoću suglasnika w ili $\mathrm{y}$. 
Bitno je napomenuti da je na fonetiku arabizama značajno uticao vokalni sistem turskog jezika, obzirom da je on bio jezik posrednik, ali i vokalni sistem drugih jezika preko kojih smo preuzmali arabizme. Zbog toga, jedan broj vokala u arabizmima doživio je veće promjene, bilo da se radi o kvalitetu ili kvantitetu. Tako je došlo do duljenja kratkih i skraćivanja dugih vokala ili umetanja novih u arapskom jeziku nepostojećih vokala.

Od osnovnih vokala dugi su, uglavnom, ostali bez većih promjena (ne uzimajući pri tom $\mathrm{u}$ obzir akcentske promjene). Od kratkih vokala ,i“ se, uglavnom, nije mijenjalo, „u“ je ponegdje prešlo $\mathrm{u}, \mathrm{o}^{\text {“, }}$, dok je ,,a“ zadržalo taj zvuk uz gore istaknute suglasnike, a uza sve ostale, s malim izuzecima, redovno se izgovara slično našem ,e“.

Ovdje možemo ubrojati asimilaciju i disimilaciju vokala, njihovo dodavanje, umetanje, gubljenje i promjenu njihovog kvantiteta. $^{18}$

Treće: Tvorba novih riječi

Hibridna grupa riječi je obrazovana na nearapskim područjima od arapske grupe riječi pomoću stranih afiksa i gotovih tuđica povezanih uz njih.

U naš jezik su prvenstveno ulazili imenski oblici arapskog jezika, tj. ponajviše imenice $\mathrm{i}$ glagoli, od kojih su derivacijom $\mathrm{i}$ kompozicijom obrazovane nove imenice, pridjevi, prilozi i glagoli. Sve to pomoću naših, ali često i turskih i perzijskih elemenata, što je rezultiralo nastankom hibridnih riječi.

a) derivacijom, tj. izvođenjem novih riječi pomoću afiksa, bilo da se radi o prefiksima (poput: iz- (is-) نَعْبِير tabiriti, na- نِيَّة nijetiti, oبَ battal) ili sufiksima, a može biti u pridjevima (poput nastavka -an, مَخْمُور mahmur-an), imenicama (poput nastavka -in, قَََّّّاب kassab(p)in) ili glagolima (poput nastavka -ova, عَاثثِقa ašik-ova-ti),

b) kompozicijom, tj. obrazovanjem složenica od dvaju ili više samostalnih riječi, tako da one daju novu izgovornu i pojmovnu cjelinu. Ovdje se, pored arapskih, koriste i naše riječi, ali i turske i

${ }^{18}$ Više o ovome vidi: Muftić Teufik, O arabizmima u srpskohrvatskom jeziku, str. 19-21. 
perzijske. Rjeđe se koriste složenice s našim riječima, poput riječi كُفْر kufur ili ćufur besjeda ili s negativnom partikulom ne-+ وَقْت nevakat.

\section{Semantičke promjene koje su se desile prilikom ulaska arabizama u bosanski jezik}

Kao što je bitno poznavati fonetske promjene prilikom ulaska arabizama u naš jezik, također je neophodno da se pojasni pitanje značenja arabizama, kao i okolnosti njihove upotrebe.

Pojedini arabizmi su nastajali od stranih elemenata, a njihova semantika je modificirana, ponekad do te mjere da im daju nijanse značenja koja uopće ne postoje u semantici arapskog jezika.

Usljed promjena uslova života i društvenih odnosa, neki arabizmi su mijenjali svoje značenje, dok neki nisu, jer nisu imali domaću ili dobru zamjenu (poput riječi duhan دُخَان) ili zbog specifičnosti značenja (poput riječi sedžada سَجََّّدة).

Faktori semantičkih promjena arabizama mogu biti: a) morfološko-jezički, b) vanjski uvjeti razvoja jezika (politički, ekonomski), i c) endogeni faktori psihološke, intelektualne, estetske i druge naravi.

Vrste promjena značenja arabizama su:

a) promjena afektivne vrijednosti, u smislu poboljšanja ili pogoršanja prvobitnog značenja,

b) promjena gramatičke vrijednosti koja se odnosi na njihovu vrstu, funkciju, rod ili broj,

c) dolazi do sinonimije, polisemije i antonimije.

\section{Primjeri arabizama u bosanskom jeziku}

U narednih 50 primjera tabelarno ćemo prikazati pojedine arabizme, ukazujući na njihov originalni oblik u arapskom jeziku.

\begin{tabular}{|c|c|c|c|}
\hline & Arabizam & $\begin{array}{c}\text { Značenje na bosanskom } \\
\text { jeziku }\end{array}$ & $\begin{array}{c}\text { U arapskom } \\
\text { jeziku }\end{array}$ \\
\hline
\end{tabular}

\footnotetext{
${ }^{19}$ Muftić Teufik, Arapsko-bosanski rječnik, El-Kalem, Sarajevo, 1997.
} 


\begin{tabular}{|c|c|c|c|}
\hline 1. & Ćatib & Pisar & كَاتِب \\
\hline 2. & Adalet & Pravednost & عَدَالَة \\
\hline 3. & Adet & Običaj & 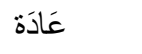 \\
\hline 4. & Adžaib & Čudna stvar & عَجَائب \\
\hline 5. & Adžemi & Neiskusan, početnik & عَجَمِيّ \\
\hline 6. & Adžeba & Izraz sumnje & عَجَباً \\
\hline 7. & Adžele & Žurba & عَجَلَة \\
\hline 8. & Hafif & Lagan, slab & خَفِفف \\
\hline 9. & Afet & Nesreća & آفَفة \\
\hline 10. & Af & Oprost & عَفْو \\
\hline 11. & $A h b a b$ & Prijatelj & أَحْبَاب \\
\hline 12. & Ahir-zeman & Doba pred smak svijeta & آخِرُ زَمَان \\
\hline 13. & Ahlak & Moral, ćud & أَخْلَاق \\
\hline 14. & Ahmak & Budala, glupan & أَحْمَق \\
\hline 15. & Akil & Pametan & عَاقِل \\
\hline 16. & Halat & Oruđe, instrumenti & آلَّة \\
\hline 17. & Alem & Zastava, simbol & عَلَم \\
\hline 18. & Gajret & Privrženost & 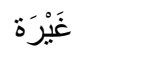 \\
\hline 19. & Emanet & Povjerenje & أََانَة \\
\hline 20. & Kahar & Žalost, tuga, briga & قََهْر \\
\hline 21. & Ashab & Prijatelj, drug & أَصْحَاب \\
\hline 22. & Asker & Vojska & عَسْكَر \\
\hline 23. & $A \check{s} i k$ & Dragi, zaljubljeni & عَاثِثِق \\
\hline
\end{tabular}




\begin{tabular}{|c|c|c|c|}
\hline 24. & Hazur & Spreman, gotov & 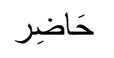 \\
\hline 25. & Hećim & Doktor, ljekar, mudrac & حَكِيم \\
\hline 26. & Bajat & Koji nije svjež & بَائتِت \\
\hline 27. & Hazna & Blagajna, riznica & 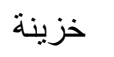 \\
\hline 28. & Baklava & Baklava, slatka pita s orasima & 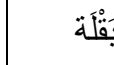 \\
\hline 29. & Hamal & Nosač & حَمَّال \\
\hline 30. & Batil & Beskoristan, pokvaren & 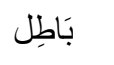 \\
\hline 31. & Fukara & Siromah, sirotinja & فُقَرَ \\
\hline 32. & Bejaz & Bijel, bjelina & 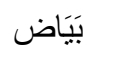 \\
\hline 33. & Belaj & Nevolja, nesreća & بَلَاء \\
\hline 34. & Fajda & Korist & فَائيَدة \\
\hline 35. & Berićet & Obilje, blagoslov & بَرَكَة \\
\hline 36. & Evlija & Sveti čovjek, dobri & أَوْلْيَاء \\
\hline 37. & Ćafir & Nevjernik & كَافِر \\
\hline 38. & Edžel & Smrtni čas, usud, smrt & أَجَل \\
\hline 39. & Ćenifa & Zahod, nužnik & كَنِف \\
\hline 40. & Devam & Trajanje, ustrajnost & دَوَام \\
\hline 41. & Ćefil & Jamac & كَفِيل \\
\hline 42. & $\begin{array}{c}\text { Ćef, ćeif, } \\
\text { ćejf }\end{array}$ & Uživanje, volja, prohtjev & كَيْف \\
\hline 43. & Dželat & Krvnik, silnik & جَلَّد \\
\hline 44. & Ćevap & Vrsta jela & كَبَاب \\
\hline 45. & Ćitab & Knjiga & كِنَاب \\
\hline 46. & Ćup & Zemljani duboki sud & 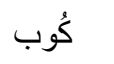 \\
\hline
\end{tabular}




\begin{tabular}{|c|c|c|c|}
\hline 47. & Ćursija & Stolica, prestolje & كُرْبِيّ \\
\hline 48. & Devam & Trajanje, ustrajnost & دَوَام \\
\hline 49. & Hala & Zahod, nužnik & خَلَاء \\
\hline 50. & Džahil & Neznalica & جَاهِل \\
\hline
\end{tabular}

\section{Značaj poznavanja arabizama u nastavi arapskog jezika}

Svako ko predaje neki strani jezik, vjerovatno se susreće sa problemom memorisanja novih riječi i izraza od strane učenika ili studenata. Nastavnici stranih jezika za taj problem pokušavaju iznalaziti razna rješenja.

Kada je u pitanju arapski jezik, postojanje arabizama u značajnoj mjeri pomaže prilikom učenja jednog broja riječi, čiji broj, kako smo to prethodno istaknuli, ne prelazi 10000 riječi. Iako je broj arabizama na prvi pogled velik, međutim, te riječi ne predstavljaju cjelokupan fond osnovnih riječi potrebnih za običnu konverzaciju, ali pomažu da se određeni pojmovi lakše usvajaju. Najbolji primjer su vjerski pojmovi i vjerski običaji koji su ustaljeni na našim prostorima, a za koje muslimani, pa čak i nemuslimani, ovih podneblja koriste arabizme ili terminologiju iz arapskog jezika.

Da bih to potvrdio, proveo sam ograničeno istraživanje među studentima prve i druge godine Islamskog pedagoškog fakulteta $\mathrm{u}$ Bihaću i postavio im par pitanja, poput: Sta su to arabizmi? Da li postoji razlika između pojmova turcizam, arabizam, orijentalizam, tuđica? Da li ti poznavanje arabizama pomaže u učenju arapskog jezika i ako je odgovor pozitivan, pojasni kako?, te zatražio od njih da navedu desetak riječi koje smatraju da su arabizmi u bosanskom jeziku.

Cilj istraživanja je bio ispitati koliko studenti poznaju ovu tematiku, ali i koliko je korisno povezivanje značenja riječi arapskog jezika sa arabizmima u bosanskom jeziku, obzirom da taj metod često koristim u svakodnevnoj nastavi.

Svi studenti su potvrdno odgovorili da znaju šta su to arabizmi i za to su naveli nekoliko primjera. Svako od njih je pojasnio šta se podrazumijeva pod pojmovima turcizam, arabizam, orijentalizam, 
tuđica, ali je samo mali broj istaknuo da pojmovi turcizam i orijentalizam obuhvataju arabizme.

Većina smatra da poznavanje arabizama olakšava učenje arapskog jezika, dok se neznatan broj njih s tim ne slaže. Naravno, svi koji smatraju da poznavanje arabizama olakšava učenje arapskog jezika, slažu se da je to zbog činjenice da su značenja arabizama u bosanskom i arapskom jeziku ista ili slična.

Svako od ispitanika je uspio nabrojati značajan broj arabizama, s tim da se dā zapaziti da su među arabizme ubrajali i riječi koje nisu porijeklom iz arapskog jezika.

Dakle, iz istraživanja možemo zaključiti da je veoma bitno izučavati arabizme, povezivati riječi arapskog jezika sa arabizmima i ukazivati na fonetske i semantičke promjene koje su se desile u tim riječima, jer nam pomažu da lakše naučimo arapski jezik.

$\mathrm{Na}$ kraju, iz ličnog iskustva mogu da konstatujem da se u nastavnom procesu stiče utisak da se stepen „stranosti“ arapskog jezika smanjuje i splamsava ukoliko se studentima skrene pažnja da neka riječ koja se koristi u bosanskom jeziku ima osnovu u arapskom jeziku, tj. ima status arabizma.

\section{Zaključak}

Na kraju ovoga rada možemo da zaključimo sljedeće:

Turcizmi su riječi preuzete iz turskog jezika. Posebno su karakteristični za jezike naroda, koji su bili pod vlašću Osmanskog carstva (grčki, bošnjački, bugarski, makedonski, srpski, jermenski), dok riječi koje vode porijeklo iz arapskog i perzijskog jezika, a na prostore Balkana su došle putem turskog jezika, imaju status turcizama.

Proučavanje arabizama i orijentalizama općenito je važno zbog nekoliko razloga, a posebno se ističe činjenica da je ovaj region bio nekoliko stoljeća pod Osmanskim carstvom,

Spoznaja o kojem se broju arabizama radi jasno ukazuje koliki je direktan uticaj ostavila arapsko-islamska kultura na same Osmanlije, a putem Osmanlija indirektno i na naše podneblje, običaje, mentalitet, razmišljanje i stil življenja. 
Arabizme su najviše širili turski vojnici, administracija, domaći muslimani, te činovnici i trgovci, a poseban uticaj imali su građani ovih govornih područja koji su se školovali u Carigradu i vjerska terminologija među muslimanima ovih podneblja,

Veoma je bitno izučavati arabizme, povezivati riječi arapskog jezika sa arabizmima i ukazivati na fonetske i semantičke promjene koje su se desile u tim riječima, jer nam pomažu da lakše naučimo arapski jezik.

\section{Literatura:}

a) Printana literatura:

1. Halilović Senahid, Pravopis bosanskoga jezika - priručnik za škole, Dom štampe, Zenica, 1999.

2. Isaković Alija, Rječnik bosanskoga jezika, Bosanska knjiga, Sarajevo, 1995.

3. Klaić Bratoljub, Rječnik stranih riječi, Nakladni zavod Matice Hrvatske, Zagreb, 1990.

4. Muftić Teufik, Arapsko-bosanski rječnik, El-Kalem, Sarajevo, 1997.

5. Muftić Teufik, O arabizmima u srpskohrvatskom jeziku, u „Prilozi za orijentalni filologiju X-XI“, Orijentalni institut, Sarajevo, 1960-61.

6. Muftić Teufik, Prilog semantičkom izučavanju arabizama u srpskohrvatskom jeziku, u „Prilozi za orijentalnu filologiju XVIII-XIX“, Orijentalni institut, Sarajevo, 1973.

7. Nametak Fehim, Književnost bosanskohercegovačkih muslimana na turskom jeziku, „Treći program Radio Sarajeva“, Sarajevo, 1978., br. 19.

8. Škaljić Abdulah, Turcizmi u srpsko-hrvatskom jeziku, Svjetlost, Sarajevo, 1966.

9. Vajzović Hanka, Orijentalizmi u književnom djelu, Institut za jezik, Sarajevo, 1999.

b) Web-stranice:

10. http://sr.wikipedia.org/srel/\%D0\%A2\%D1\%83\%D1\%80\%D1\%86\%D0\%B8\%D $0 \% \mathrm{~B} 7 \% \mathrm{D} 0 \% \mathrm{BC} \% \mathrm{D} 0 \% \mathrm{~B} 8$

11. http://www.hercegbosna.org/forum/kultura-knjizevnost-umjetnost/turcizmi-uhrvatskom-jeziku-muhamed-had-ijahi-t2067.html 
Hajrudin Hodzic, MA

\section{ARABISM IN THE BOSNIAN LANGUAGE AND THE IMPORTANCE OF ITS KNOWLEDGE IN THE PROCESS OF THE ARABIC LANGUAGE EDUCATION}

\section{SUMMARY}

Arabism is words of Arabic origin, which has been transmitted through the Turkish language and established itself in the Bosnian language. Arabism is often studied under the name of Turkish loanword, since it arrived in the Bosnian language through Turkish language, and is routinely considered to be of Turkish origin, although this term includes not only the words of Turkish, but also words from Arabic and Persian languages.

The aim of this work is to present Arabism in Bosnian language: defining the concept of Arabism, and the differences between Arabism and Turkish words, an explanation how Arabism came to our region and how many Arabism can be found in our language. The paper referred to the phonetic and semantic changes that have occurred during their entry into the Bosnian language, stating the practical examples of Arabism in our language.

The paper has also given attention to the importance and significance of the study of Arabism, especially in teaching of the Arabic language.

Keywords: Arabism, Turkish loanwords, Orientalism, voice changes, a hybrid word, Arabic language, Turkish language 


$$
\text { م. خير الدين هوجيتش }
$$

الألفاظ ذات الأصول العربية في اللغة البوسنوية وأهمية معرفتها في تعليم اللغة العربية

\section{خلاصة البحث}

الألفاظ ذات الأصول العربية (ARABIZAM) هي كلمات نقلت في الغالب إلى الى الئ

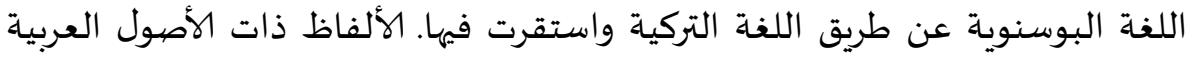

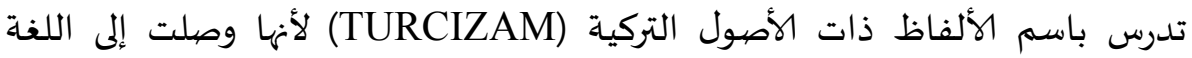

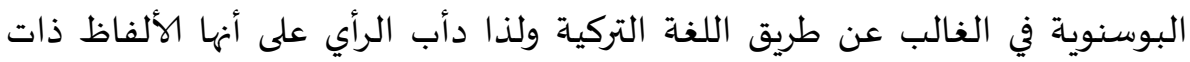

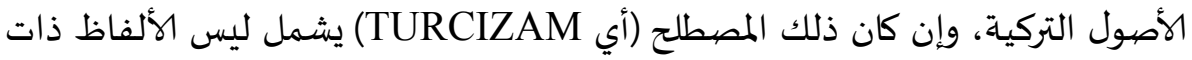
الأصول التركية فحسب وإنما غيرها مثل الألفاظ ذات آلرات الأصول العربية والفارسية.

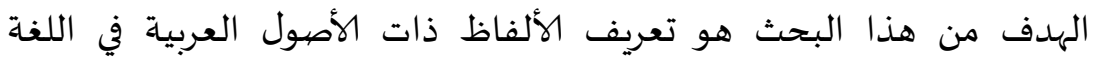

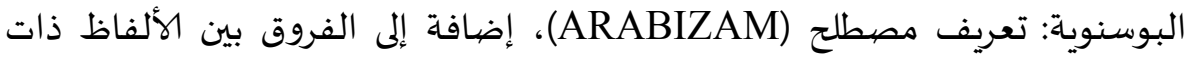

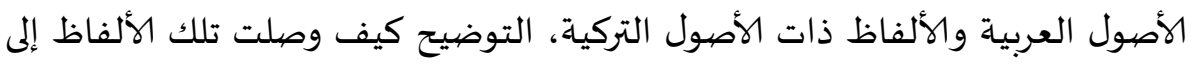

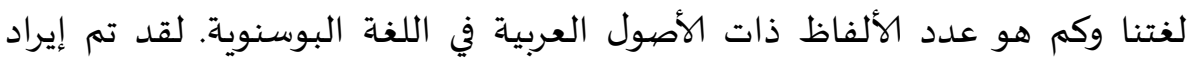

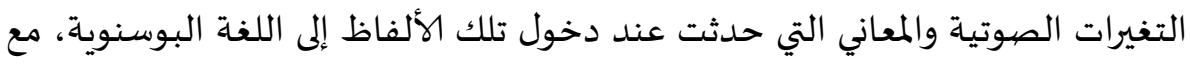

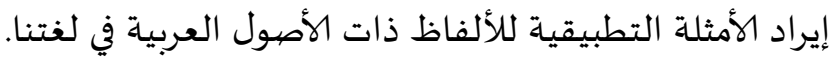
تناول البحث كذلك العناية بأهمية ومكانة تعليم الألفاظ ذات الأصيول العربية، خاصة في مجال تعليم اللغة العربية.

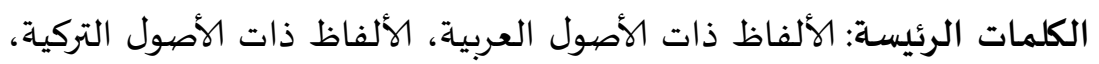

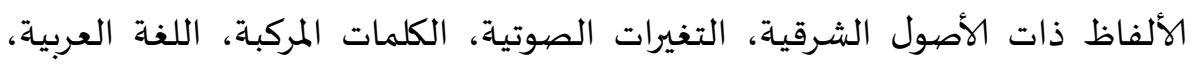

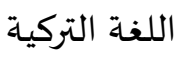

